\title{
CHRONIC BEACH EROSION INDUCED BY COASTAL STRUCTURES IN CHELEM, YUCATÁN
}

\author{
M. Alejandra Lira-Pantoja ${ }^{1}$, Alec Torres-Freyermuth $^{1}$, Christian M. Appendini ${ }^{1}$, Diana Fernández ${ }^{1}$, \\ Paulo Salles ${ }^{1}$, E. Tonatiuh Mendoza ${ }^{1}$, José López ${ }^{1}$, Adrián Pedrozo-Acuña ${ }^{2}$
}

\begin{abstract}
The Yucatan coastline has been experiencing beach erosion during the past few decades, reaching critical levels at some locations such as in Chelem beach located near the Progreso Pier. Despite this problem, only few studies have been devoted to investigate the role of coastal structures on explaining the high erosion rates. Therefore, the aim of this work is to evaluate the effects of the 6-km long Progreso Pier on the nearshore wave transformation and alongshore sediment transport in the study area. Field surveys were conducted in a monthly basis to measure the changes in the beach profiles. Furthermore, wave conditions were determined with an ADCP installed at $8 \mathrm{~m}$ water depth. Observations confirmed the high erosion trends $(1 \mathrm{~m} /$ year $)$ that have produced coastal infrastructure damage and property loss along $10 \mathrm{~km}$ of coast. The wave measurements were employed as forcing on a third generation wave transformation model (MIKE $21 \mathrm{SW}$ ). Firstly, the numerical model is implemented in the study area for two different scenarios, with and without the Progreso Pier structure, in order to estimate the nearshore wave conditions. Subsequently, wave conditions predicted at $5 \mathrm{~m}$ water depth were employed for the estimation of longshore sediment transport in the study area. The modeling results showed that the pier acts as a large scale wave-sheltering structure that induces important longshore sediment transport gradients during mean wave conditions coming from the NE. On the other hand, during winter storms, when the dominant direction of the waves is from the NNW, the structure does not seem to play an important role on wave transformation into the study area. As a result, the Progreso Pier enhances beach erosion in the Chelem area by inducing longshore sediment transport gradients during mean wave climate and decreasing the capacity of waves to recover the summer beach profile.
\end{abstract}

Keywords: Beach erosion; coastal structures; Yucatan, México; Chelem beach

\section{INTRODUCTION}

The Yucatan coastline undergoes a series of changes induced either by anthropogenic interventions or natural wave dynamics. Despite the mild-wave conditions in the study area $(\mathrm{Hs}=1 \mathrm{~m})$, beach erosion is critical in many locations. The erosion rates present an important alongshore variability ascribed to the combination of a mean wave persistence from the NNW sector and the presence of coastal structures. The most critical area corresponds to the Chelembeach (Figure 1), located westward from the approximately 7-km long Progreso Pier.

Appendini et al. (in press) conducted a regional sediment transport study and showed no sediment transport gradients in the Chelem area, suggesting that the coastline in this area is stable given a constant supply of sand and the absence of coastal infrastructure. However, this coastline has been experiencing severe beach erosion during the past few decades, with an erosion rate of 0.9 m/year during the 1948-1978 period (MeyerArendt, 1993), and a similar trend in recent years when the beach width has been reduced by approximately $20 \mathrm{~m}$ throughout the last 40 years (Lopez Gutierrez, personal communication). For this reason, it is important to study the coastal processes occurring in this region in order to identify the causes that have led to this problem. Therefore, the aim of this work is twofold. Firstly, to conduct field surveys in order to characterize the topo-bathymetry and the wave conditions in the Chelem area. Secondly, to evaluate the effect of the Progreso Pier on the coastal dynamics by means of wave transformation and sediment transport numerical models.

\footnotetext{
${ }^{1}$ Laboratorio de Ingeniería y Procesos Costeros, Instituto de Ingeniería, Universidad Nacional Autónoma de México, Sisal, Yucatán, 92718, México

2 Instituto de Ingeniería, Universidad Nacional Autónoma de México, Cd. Universitaria, México, D.F., 04360, México
} 


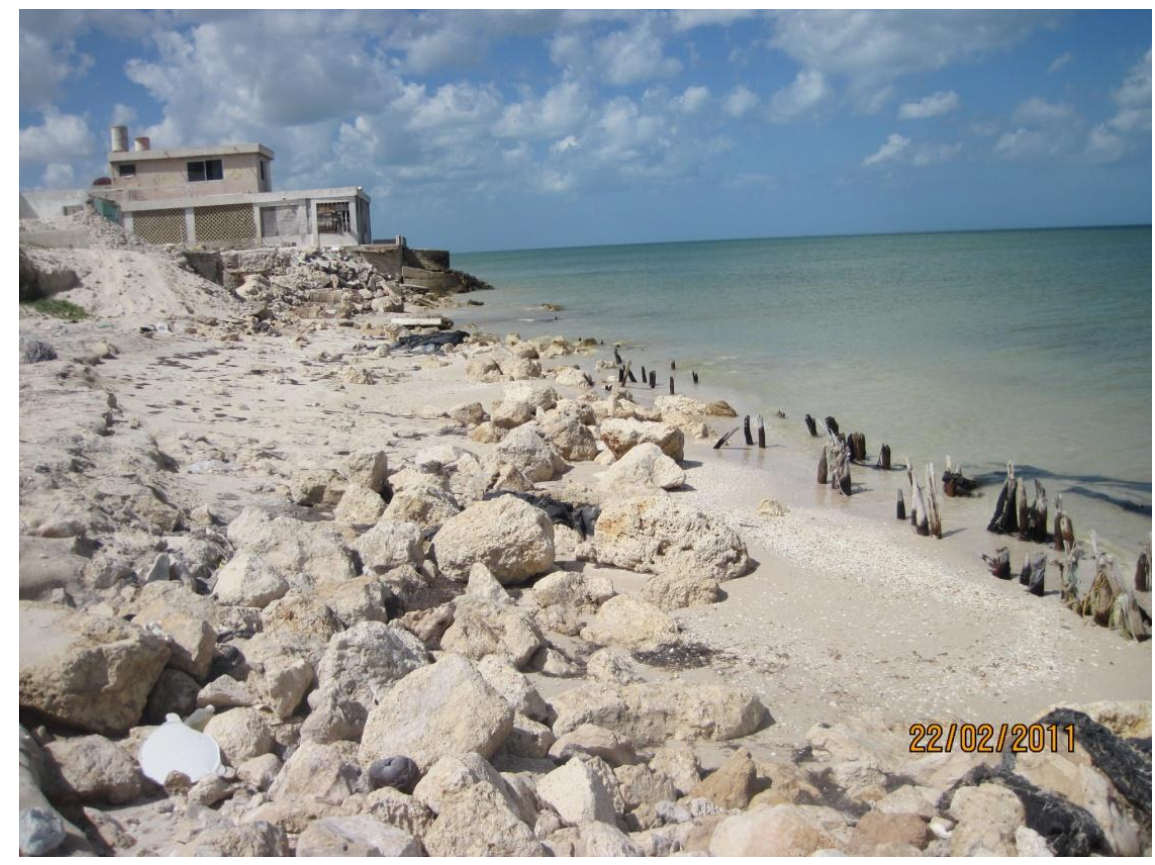

Figure 1: Beach erosion in Chelem.

\section{STUDY AREA}

Chelem beach is located $5 \mathrm{~km}$ west of the Progreso pier and approximately $1 \mathrm{~km}$ west of the Yucalpetén port (Figure 2). It has a subtropical sub-humid climate and the temperature varies between $25^{\circ}$ and $40^{\circ}$ Celsius. The prevailing wind direction is NE and SE, although the strongest come from the North and NE. The sediment in this beach has a mean grain diameter $\left(d_{50}\right)$ of approximately $0.34 \mathrm{~mm}$. The beach at Chelem is one of the main vacation destinations for the people of Yucatan. Moreover, many foreign visitors own or rent houses at this beach during the summer/winter months, representing an important economic income for the Yucatan state.

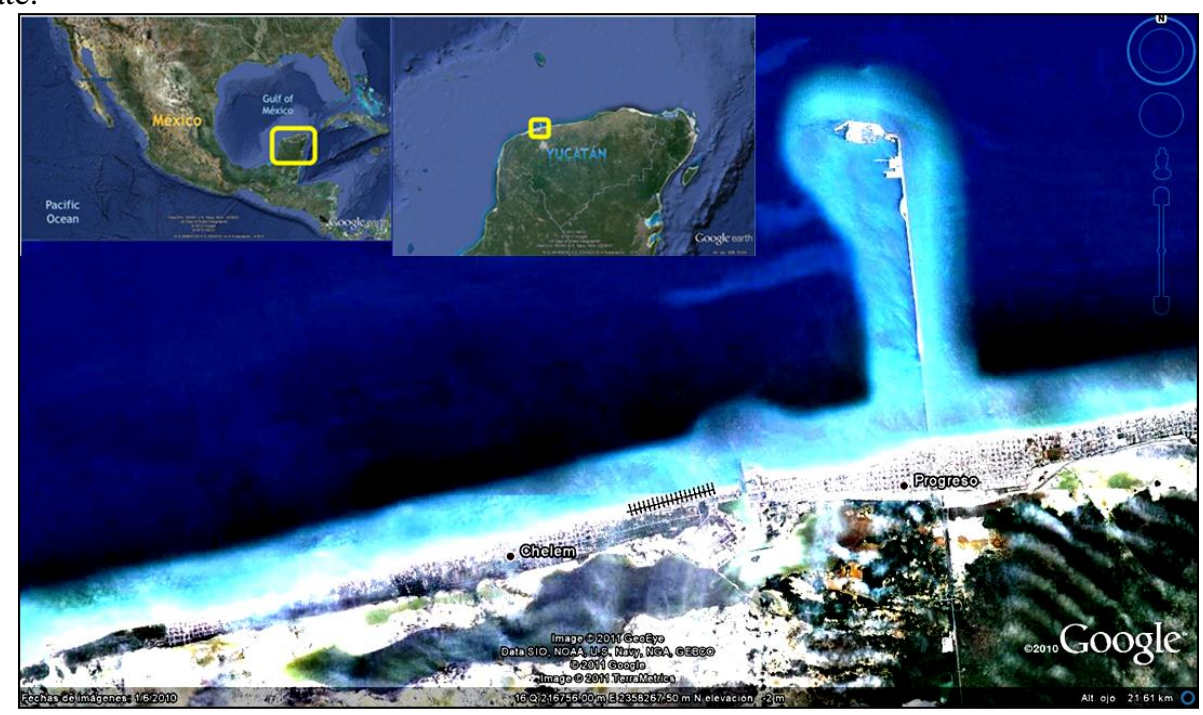

Figure 2: Study Area located in the north of the Yucatán peninsula. 
The construction of Progreso pier has been taken place over the last 60 years. The first stage was conducted between 1937 and 1941, which consistsof146 concrete arches (Figure 3a) that allow the sediment flow through the $2.1 \mathrm{~km}$ length of this section (Moreno et al, 2004). Then, in 1985 the pier was extend further offshore in order to reach higher depths, consisting of a $4.7 \mathrm{~km}$ long impermeable structure. During mean wave conditions, the predominant wave direction is NE, whereas winter storms arrived from the NW to $\mathrm{N}$ sector.

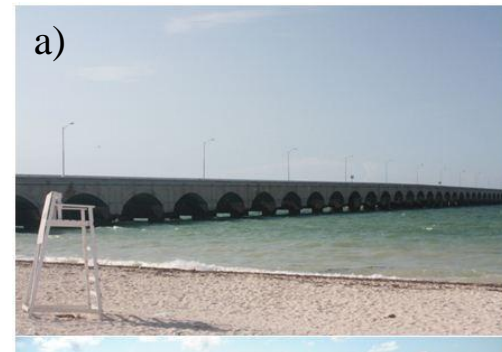

b)

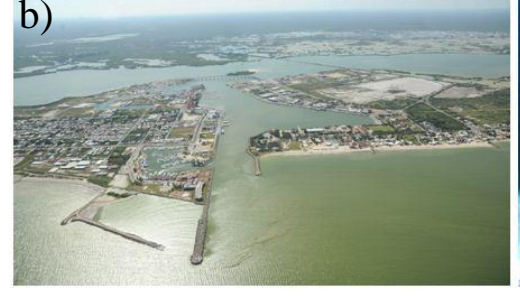

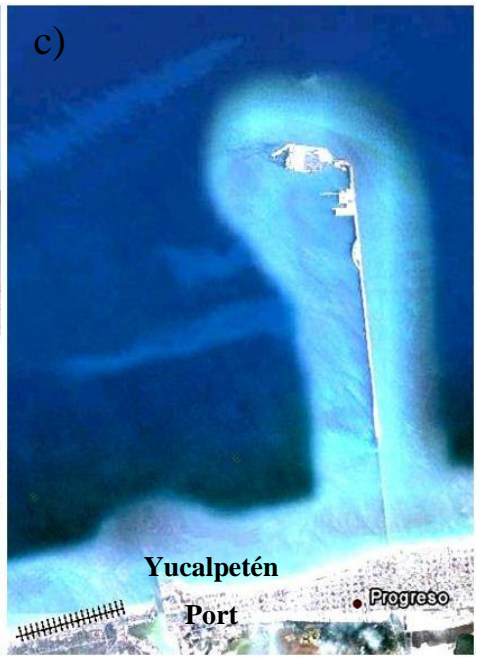

Figure 3: a) First part of the Progresso pier consisting of 146 concrete arches; b) Aerial view of the Yucalpetén port located east from the study area (www.aerozoom.com.mx); c) Planform view of the study area including the Progreso Pier, the Yucalpetén Port, and the Chelem beach.

\section{DATA COLLECTION AND METHODOLOGY}

\section{Monitoring}

Topo-bathymetric surveys were conducted in the study area between June of 2010 and May of 2011. A monitoring program was conducted in a $2 \mathrm{~km}$ section of the Chelem beach with the purpose to evaluate the beach nourishment evolution that took place in August and September of 2010. The 2km were divided in 19 transects $100 \mathrm{~m}$ spaced from each other (Figure 4). This allows characterizing the shoreline evolution along that period.

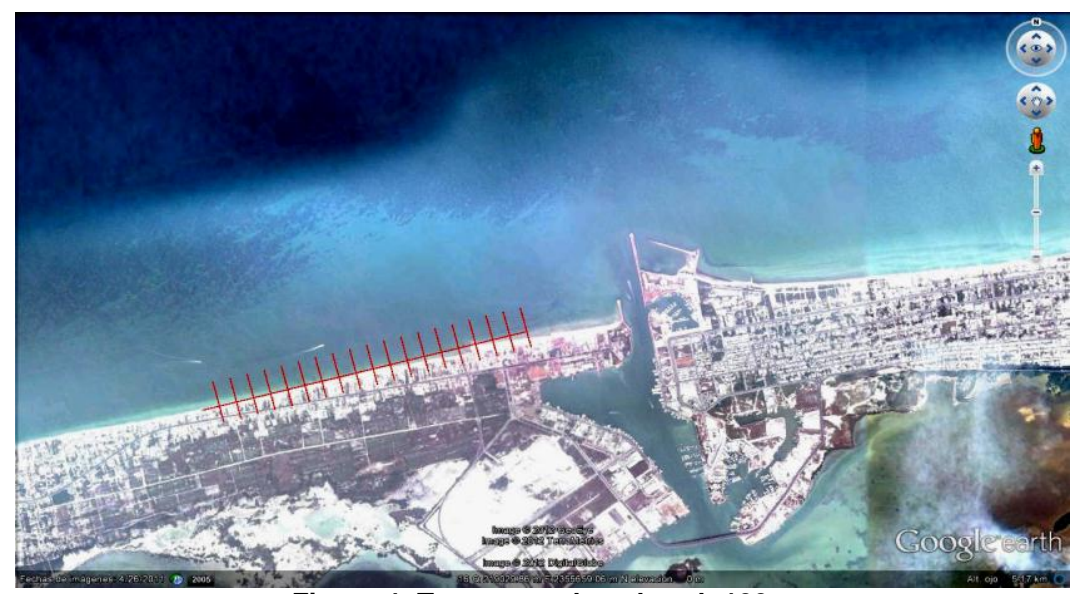

Figure 4: Transects placed each 100m 
During the first campaign (pre-nourishment), sand samples were collected and analyzed to determine the grain size distribution.

\section{Wave measurements}

An Acoustic Doppler Current Profiler (ADCP) was installed approximately 8km offshore, at $8 \mathrm{~m}$ water depth, to measure wave conditions (significant wave height, peak wave period and mean wave direction) each hour. This information was employed for the forcing in the wave model. Figure 5show the wave roses reaching the coast during the two measuring time periods. The measuring time periods corresponds to winter storms (17/06/2010-02/01/2011) and calm wave conditions(05/03/2011-15/06/2011), respectively. It is clear that waves arrive from the NE during mean wave conditions, whereas storm waves come from the NW to N.

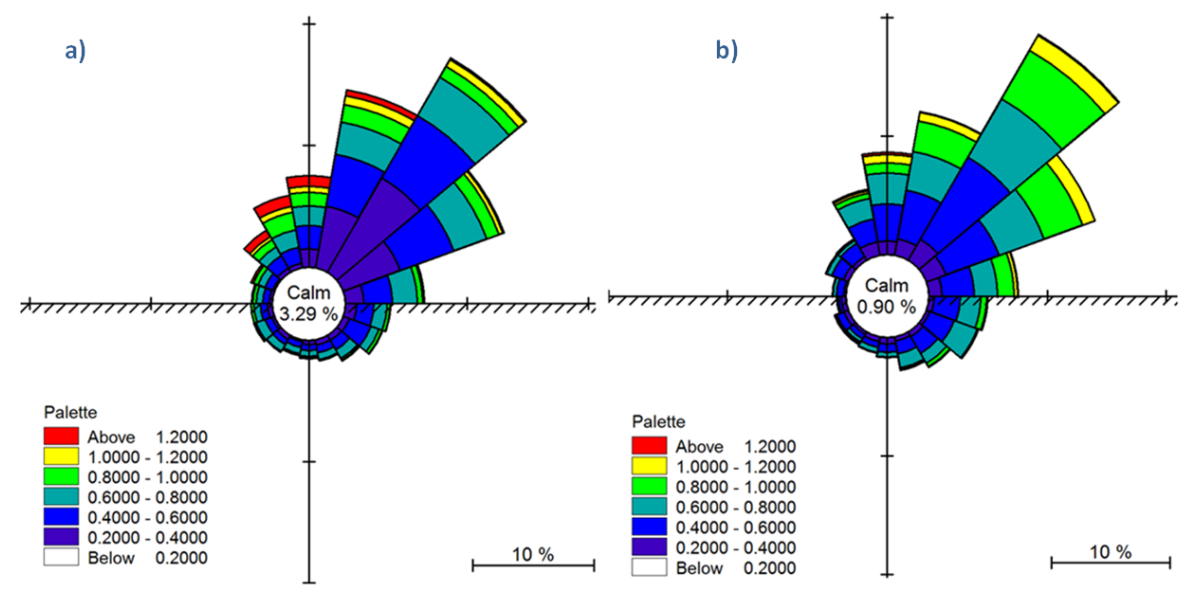

Figure 5: Wave direction and height of the waves that reached the coast during the measuring period; a)from June 2010 - Jan 2011 b) March2011- June 2011

\begin{tabular}{|c|c|c|}
\hline & June 2010 - Jan 2011 & March2011- June 2011 \\
\hline Most frequent wave & $\begin{array}{c}H s=0.47 \mathrm{~m} \\
\text { Direction }=54^{\circ}\end{array}$ & $\begin{array}{c}H s=0.564 \\
\text { Direction }=54^{\circ}\end{array}$ \\
\hline $\begin{array}{l}\text { Maximum wave } \\
\text { height }\end{array}$ & $\begin{array}{c}H s=1.85 m \\
\text { Direction }=314^{\circ}\end{array}$ & $\begin{array}{c}H s=1.61 \mathrm{~m} \\
\text { Direction }=4^{\circ}\end{array}$ \\
\hline
\end{tabular}

\section{NUMERICAL MODEL}

The MIKE 21 Spectral Wave Model (SW), developed by DHI (2011),was used to simulate the wave transformation and dissipation in the study area. The model domain (Figure 6) is $34.2 \mathrm{~km} \mathrm{x} 10.6 \mathrm{~km}$ with a maximum depth of $10 \mathrm{~m}$. An unstructured mesh consisting of 17,283 nodes and 33,858 elements with a length of approximately $90 \mathrm{~m}$. The data collected by the ADCP was employed to determine nearshore wave conditions in front of Chelem area. More specifically, it was used to establish the nearshore wave characteristics for each period in the two different scenarios. 


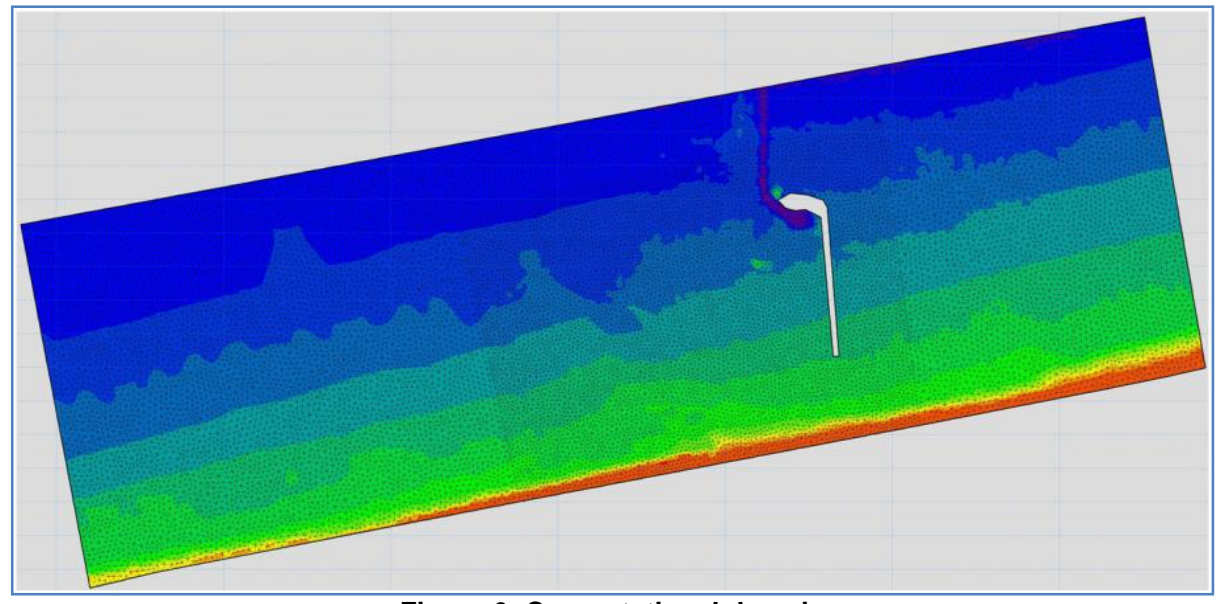

Figure 6: Computational domain

Subsequently, five different points were selected for the sediment transport calculations by means of a longshore sediment transport model (LITDRIFT). The latter allows us to evaluate the effects of the Progreso Pier on the coastal dynamics, based on scenarios with and without the Progreso pier (Figure 7).A table is presented comparing each simulation for both time series (Table 2).
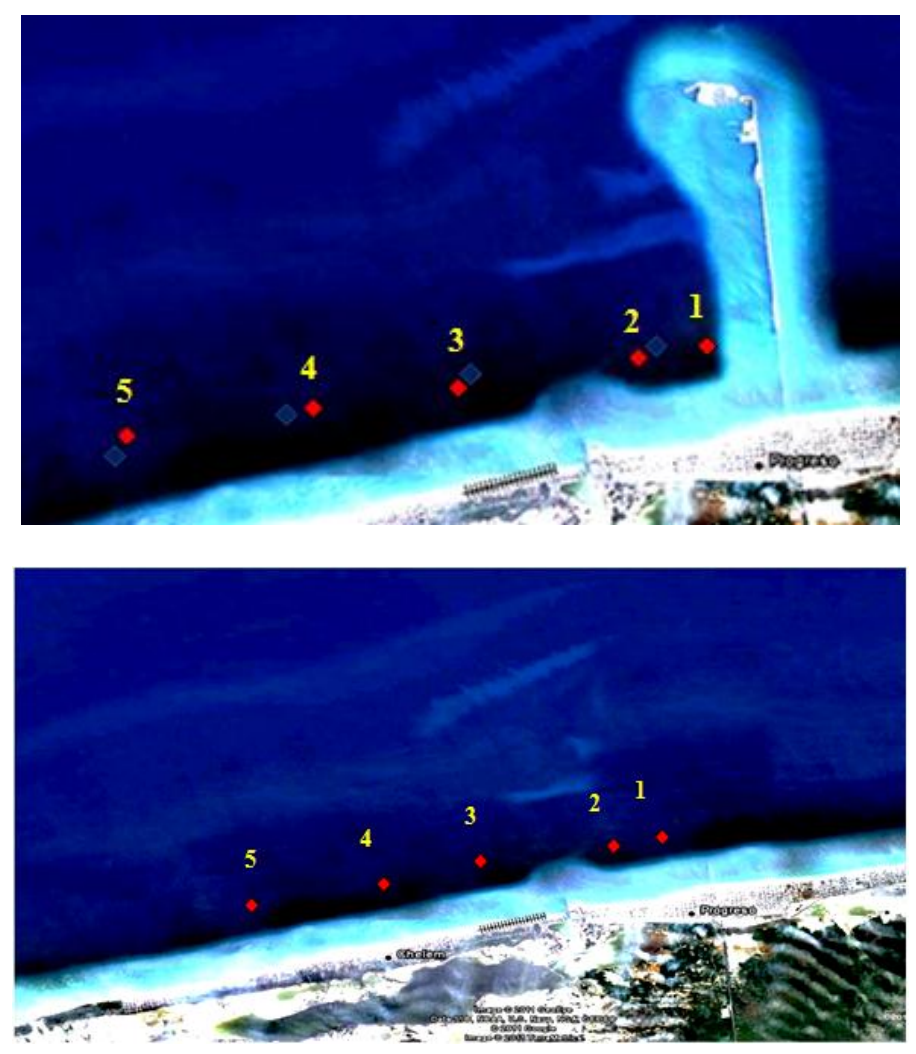

Figure 7: Five representative points of the littoral drift, analyzed with and without the structure 


\section{RESULTS}

Based on the beach surveys we identified four different regions along the $2 \mathrm{~km}$ of beach. The most stable (denoted in pink inFigure 8), corresponds to that area between two small groins. The second region (green area) is downdrift the second groin and hence it is strongly affected by this structure. In the most critical area (red area) the sea has reached the houses in the shoreline and there is hardly any change in the beach profile in time. Finally, the most downstream sector (yellow) presented some seasonal variability. The volume of sand per meter is plotted against the date of the surveys (Figure 9). It is worth to mention that the sudden gain of volume in the first two profiles is due to a little nourishment that took place during those dates. It is clear that while the groins help to keep the beach in the first section, they have a detrimental effect on the downdrift zone.

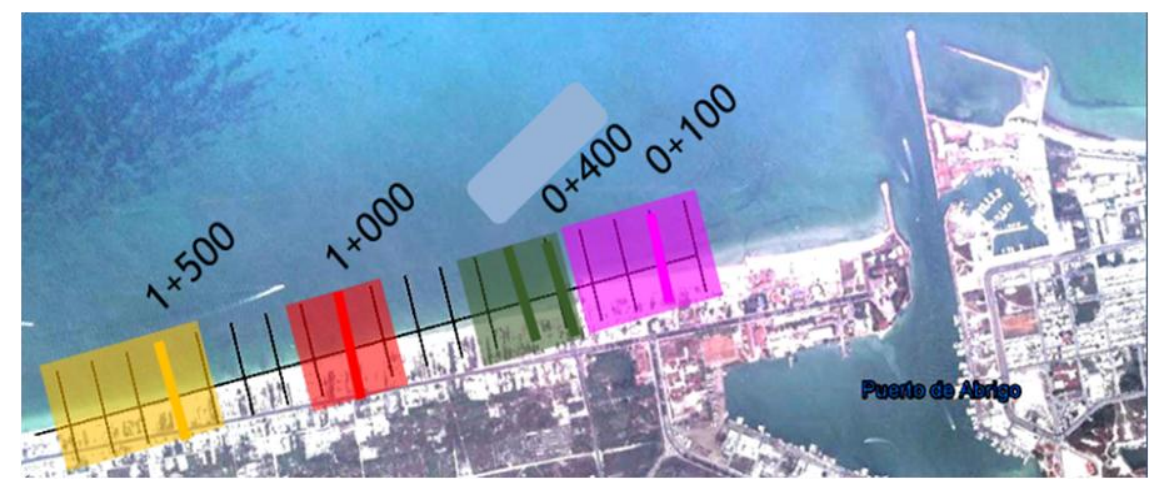

Figure 8: Characteristic zones of the study area.

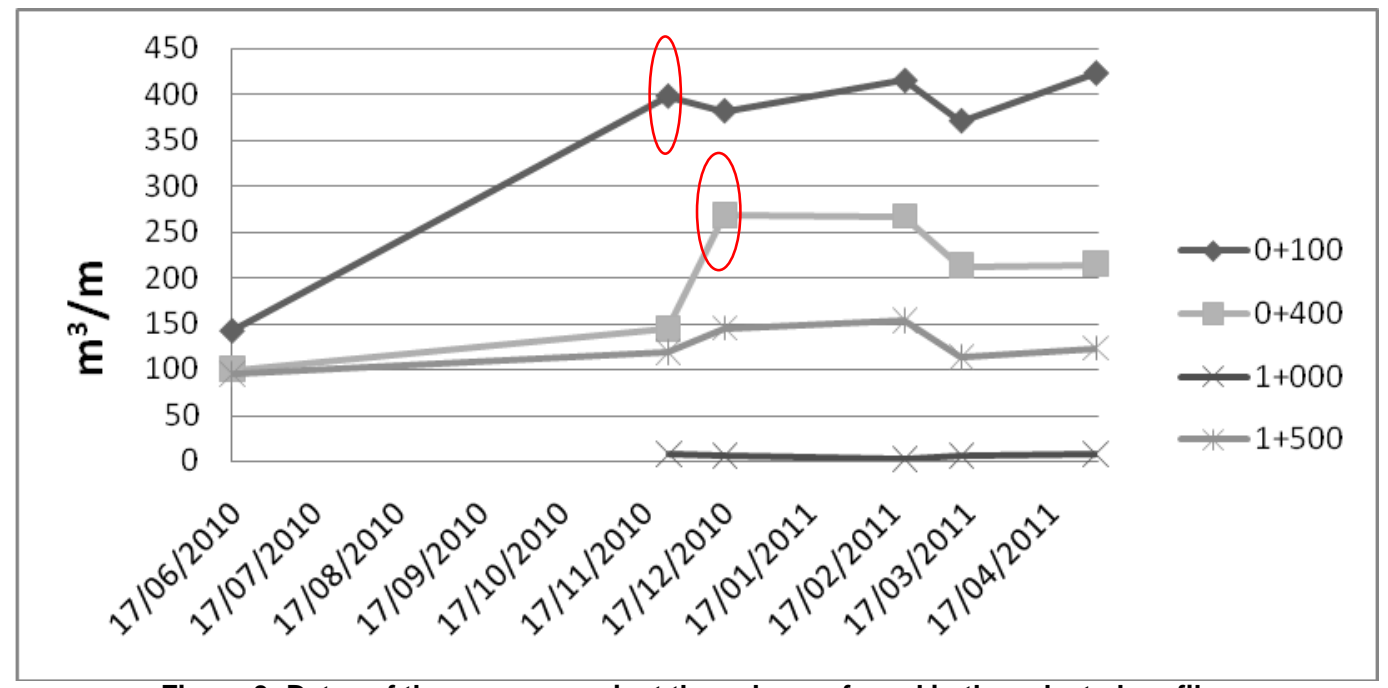

Figure 9: Dates of the surveys against the volume of sand in the selected profiles

The results of the mean grain size distribution along the $2 \mathrm{~km}$ of beach is as shown in Figure 10;Error! No se encuentra el origen de la referencia., the $D_{50}$ 'svary from 0.28 to $0.46 \mathrm{~mm}$, the latter is from the profile that presents the most severe erosion case. 


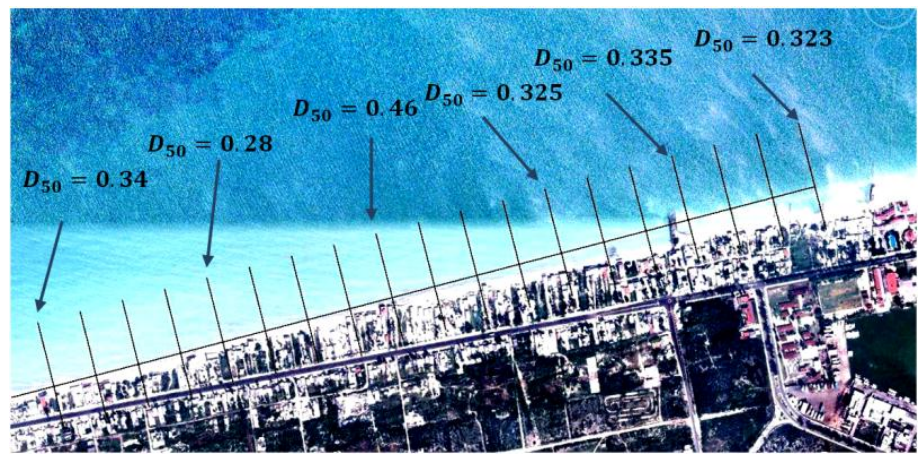

\section{Wave characteristics}

Figure 10: Mean grain diameter along the study area.

Based on the wave modeling, the structure induces a drastic wave transformation reflected in the wave height and direction under mean wave conditions (see Table 2). There is a reduction for the most frequent wave of approximately $0.30 \mathrm{~m}$ and a change in direction ( $\sim 50$ degrees). It is important to note that the higher waves coming from the NW are less affected by the Progreso Pier. The effect of the structure on the wave height and direction is significant during mean wave conditions, whereas differences for the most energetic case (highest wave heights) become negligible for the two cases. Therefore, the results show that we move farther from the pier, the difference between the results with and without the structure become negligible (see P05 in Table 2).

\begin{tabular}{|c|c|c|c|}
\hline \multicolumn{2}{|c|}{ P01 } & With Structure & W/o Structure \\
\hline \multirow[t]{2}{*}{ June 2010 - Jan 2011} & Most frequent wave & $\begin{aligned} H s & =0.06 m \\
\theta & =326^{\circ}\end{aligned}$ & $\begin{aligned} H s & =0.31 \mathrm{~m} \\
\theta & =21.5^{\circ}\end{aligned}$ \\
\hline & Maximum wave height & $\begin{aligned} H s & =1.07 m \\
\theta & =320^{\circ}\end{aligned}$ & $\begin{array}{c}H s=1.24 m \\
\theta=343.5^{\circ}\end{array}$ \\
\hline \multirow[t]{2}{*}{ March2011- June 2011} & Most frequent wave & $\begin{aligned} H s & =0.09 m \\
\theta & =337^{\circ}\end{aligned}$ & $\begin{array}{c}H s=0.3 m \\
\theta=20.4^{\circ}\end{array}$ \\
\hline & Maximum wave height & $\begin{aligned} H s & =0.63 m \\
\theta & =307^{\circ}\end{aligned}$ & $\begin{aligned} H s & =0.82 \mathrm{~m} \\
\theta & =346^{\circ}\end{aligned}$ \\
\hline \multicolumn{2}{|c|}{$\frac{1}{\mathrm{P} 02}$} & With Structure & W/o Structure \\
\hline \multirow[t]{2}{*}{ June 2010 - Jan 2011} & Most frequent wave & $\begin{aligned} H s & =0.06 m \\
\theta & =342^{\circ}\end{aligned}$ & $\begin{aligned} H s & =0.32 \mathrm{~m} \\
\theta & =18.1^{\circ}\end{aligned}$ \\
\hline & Maximum wave height & $\begin{array}{c}H s=1.2 m \\
\theta=331^{\circ}\end{array}$ & $\begin{aligned} H s & =1.25 m \\
\theta & =343^{\circ}\end{aligned}$ \\
\hline \multirow[t]{2}{*}{ March2011- June 2011} & Most frequent wave & $\begin{aligned} H s & =0.25 m \\
\theta & =342^{\circ}\end{aligned}$ & $\begin{array}{c}H s=0.29 \mathrm{~m} \\
\theta=18^{\circ}\end{array}$ \\
\hline & Maximum wave height & $\begin{aligned} H s & =0.72 m \\
\theta & =327^{\circ}\end{aligned}$ & $\begin{aligned} H s & =0.82 \mathrm{~m} \\
\theta & =346^{\circ}\end{aligned}$ \\
\hline \multicolumn{2}{|c|}{ P03 } & With Structure & W/o Structure \\
\hline \multirow[t]{2}{*}{ June 2010 - Jan 2011} & Most frequent wave & $\begin{array}{c}H s=0.18 m \\
\theta=18^{\circ}\end{array}$ & $\begin{aligned} H s & =0.3 m \\
\theta & =18^{\circ}\end{aligned}$ \\
\hline & Maximum wave height & $\begin{aligned} H s & =1.24 m \\
\theta & =338^{\circ}\end{aligned}$ & $\begin{array}{c}H s=1.2 m \\
\theta=344^{\circ}\end{array}$ \\
\hline \multirow[t]{2}{*}{ March2011- June 2011} & Most frequent wave & $\begin{aligned} H s & =0.27 m \\
\theta & =342^{\circ}\end{aligned}$ & $\begin{array}{c}H s=0.28 m \\
\theta=18^{\circ}\end{array}$ \\
\hline & Maximum wave height & $\begin{aligned} H s & =0.77 m \\
\theta & =339^{\circ}\end{aligned}$ & $\begin{array}{c}H s=0.8 m \\
\theta=346^{\circ}\end{array}$ \\
\hline \multicolumn{2}{|c|}{ P04 } & With Structure & W/o Structure \\
\hline \multirow[t]{2}{*}{ June 2010 - Jan 2011} & Most frequent wave & $\begin{array}{c}\mathrm{Hs}=0.171 \mathrm{~m} \\
\theta=18^{\circ}\end{array}$ & $\begin{array}{c}\mathrm{Hs}=0.32 \mathrm{~m} \\
\theta=18^{\circ}\end{array}$ \\
\hline & Maximum wave height & $\mathrm{Hs}=1.27 \mathrm{~m}$ & $\mathrm{Hs}=1.25 \mathrm{~m}$ \\
\hline
\end{tabular}




\begin{tabular}{|c|c|c|c|}
\hline & & $\theta=344^{\circ}$ & $\theta=343^{\circ}$ \\
\hline \multirow[t]{2}{*}{ March2011- June 2011} & Most frequent wave & $\begin{aligned} \mathrm{Hs} & =0.29 \mathrm{~m} \\
\theta & =342^{\circ}\end{aligned}$ & $\begin{aligned} \mathrm{Hs} & =0.3 \mathrm{~m} \\
\theta & =10^{\circ}\end{aligned}$ \\
\hline & Maximum wave height & $\begin{aligned} \mathrm{Hs} & =0.83 \mathrm{~m} \\
\theta & =340^{\circ}\end{aligned}$ & $\begin{aligned} \mathrm{Hs} & =0.85 \mathrm{~m} \\
\theta & =345^{\circ}\end{aligned}$ \\
\hline \multicolumn{2}{|c|}{ P05 } & With Structure & W/o Structure \\
\hline \multirow[t]{2}{*}{ June 2010 - Jan 2011} & Most frequent wave & $\begin{array}{c}\mathrm{Hs}=0.31 \mathrm{~m} \\
\theta=18^{\circ}\end{array}$ & $\begin{array}{c}\mathrm{Hs}=0.31 \mathrm{~m} \\
\theta=18^{\circ}\end{array}$ \\
\hline & Maximum wave height & $\begin{aligned} \mathrm{Hs} & =1.24 \mathrm{~m} \\
\theta & =345^{\circ}\end{aligned}$ & $\begin{aligned} \mathrm{Hs} & =1.23 \mathrm{~m} \\
\theta & =345^{\circ}\end{aligned}$ \\
\hline \multirow[t]{2}{*}{ March2011- June 2011} & Most frequent wave & $\begin{aligned} \mathrm{Hs} & =0.29 \mathrm{~m} \\
\theta & =18.1^{\circ}\end{aligned}$ & $\begin{aligned} \mathrm{Hs} & =0.29 \mathrm{~m} \\
\theta & =18.1^{\circ}\end{aligned}$ \\
\hline & Maximum wave height & $\begin{aligned} \mathrm{Hs} & =0.83 \mathrm{~m} \\
\theta & =340^{\circ}\end{aligned}$ & $\begin{aligned} \mathrm{Hs} & =0.84 \mathrm{~m} \\
\theta & =347^{\circ}\end{aligned}$ \\
\hline
\end{tabular}

\section{Sediment Transport}

Employing the propagated time series corresponding to nearshore wave conditions, the LITDRIFT model was used to calculate the sediment transport rates. This analysis does not explicitly incorporate the presence of coastal structures in the study area. However, the effect of the Progreso Pier is implicitly incorporated through the wave conditions from the two-dimensional wave transformation. TheFigure 11 shows the net sediment transport rates in $\left(\mathrm{m}^{3}\right.$ /year) and the transport direction in the selected points. It can be seen that the transport direction on the first two points is different owing to diffraction effects. More importantly, a significant alongshore sediment transport gradient is observed in the study area.

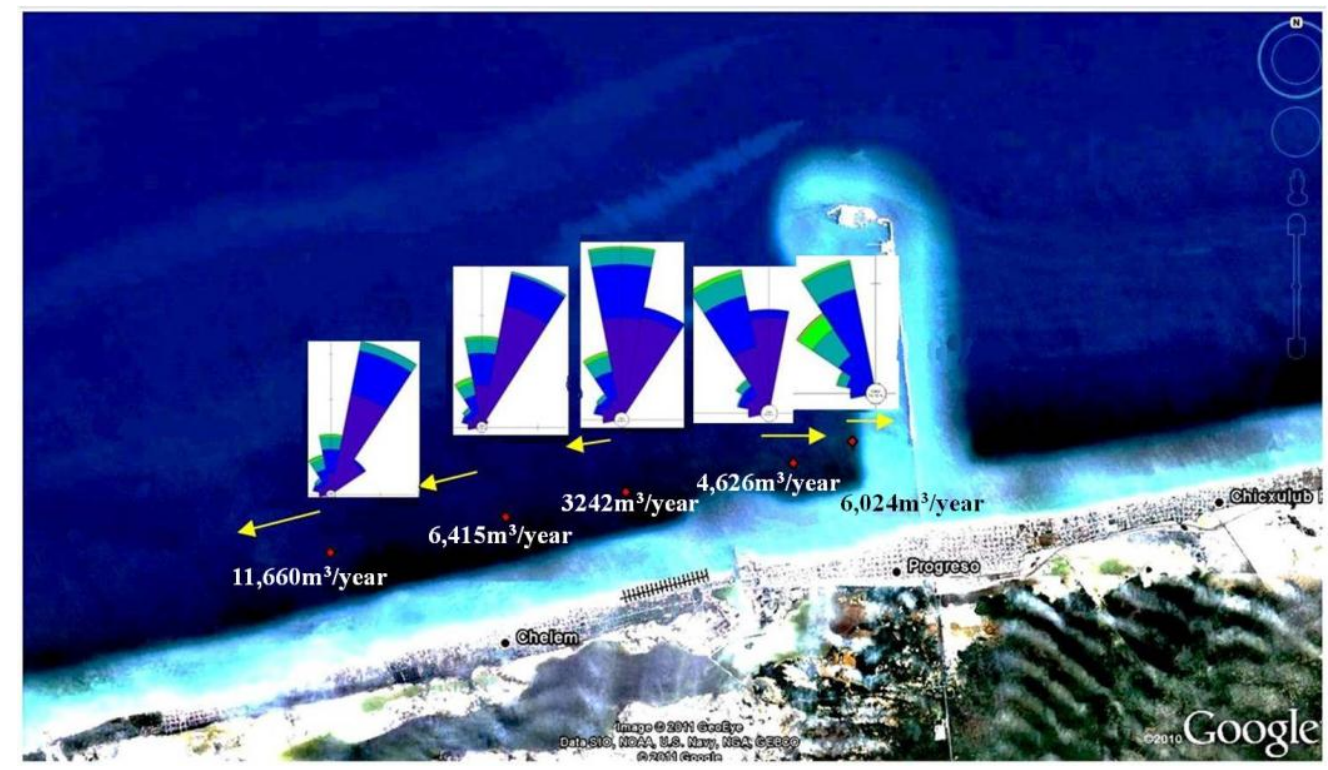

Figure 11: Sediment transport rates for the case with the structure.

On the other hand, the results obtained without the structure show that the net transport is westward at all points. In the Figure 12, it can be observed that the alongshore sediment transport is uniform without significant alongshore sediment transport gradients. Also the wave roses show that the predominant direction of the waves is the one that dictates the general direction of sediment transport. 


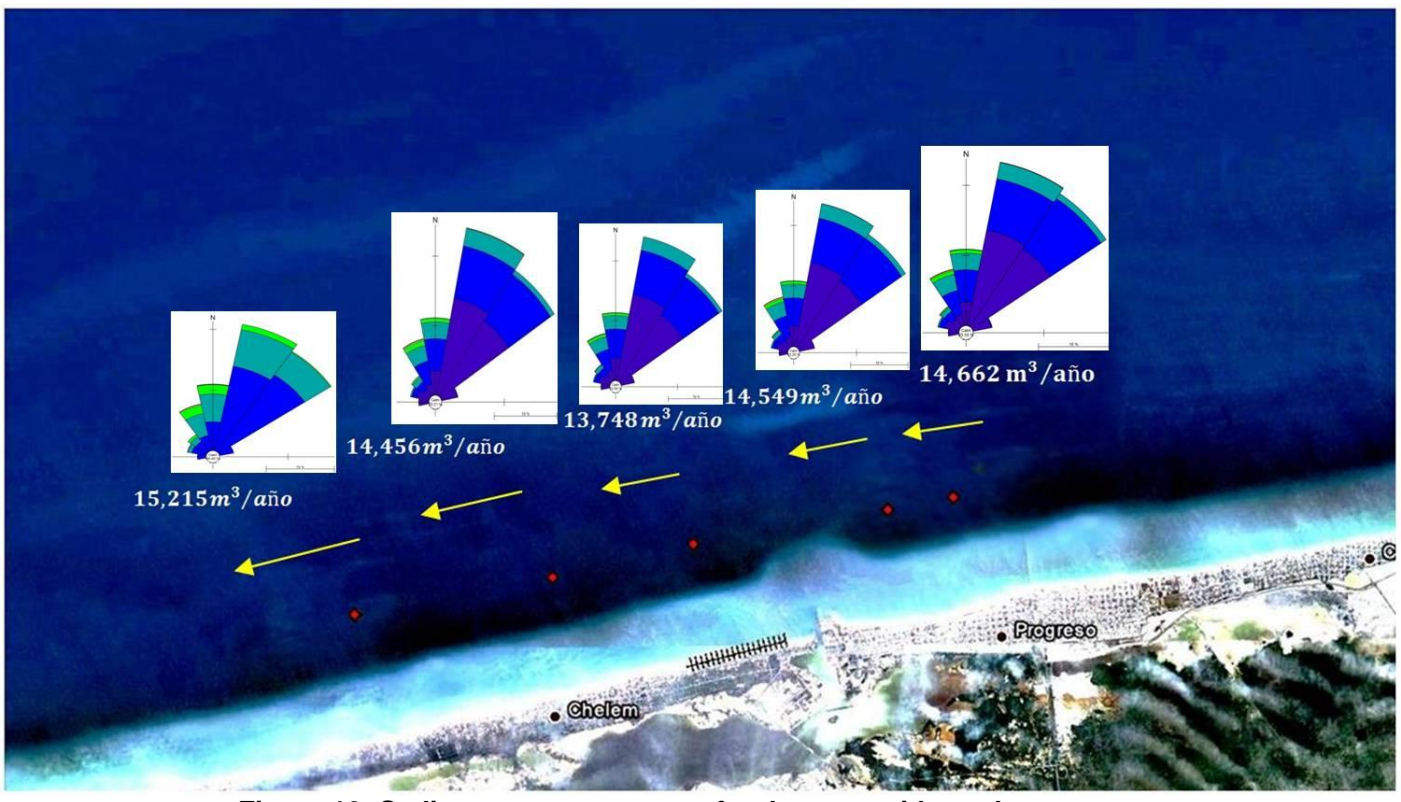

Figure 12: Sediment transport rates for the case without the structure.

\section{CONCLUSIONS}

Field observations in the Chelem beach are consistent with the high erosional rates (1m/year) reported in previous studies. The wave measurements were employed as the forcing of a wind-wave numerical model for the scenarios with and without the Progreso Pier structure. The modeling results show that the pier acts as a large scale wave-sheltering structure that induces important alongshore sediment transport gradients under mean wave conditions. Moreover, the wave height decrease under such conditions should diminish the summer profile recovery in the study area. On the other hand, during winter storms, with wave conditions arriving from the NNW, the structure does not seem to play an important role on wave transformation and hence beach erosion due to cross-shore sediment transport take place. Therefore, the Progreso Pier enhances beach erosion in the Chelem area by both inducing alongshore gradients in sediment transport and decreasing the beach recovery capability.

\section{ACKNOWLEDGMENTS}

Thepresentstudywassupportedby CONACYT FOMIX-YUCATAN Project 106400: "Peligro, vulnerabilidad y riesgo asociado a la erosión e inundaciones en el litoral del Estado de Yucatán. Diagnóstico, pronóstico y propuestas de mitigación y conservación”. We would like to thank Ismael MariñoTapia from the Research and Advanced Studies (CINVESTAV, Mérida Unit) for providing the bathymetry around the Progreso pier. The authors would like to thank Sergio Medellin and Rodrigo Medellin from Aerozoom for providing the oblique aerial photograph of Yucalpetén port.

\section{REFERENCES}

Appendini, C.M., Salles, P., Mendoza, E.T., López, J., Torres-Freyermuth, A., In press. Longshore sediment transporton the Northern coast of the Yucatan Peninsula. In Journal of Coastal Research.

Meyer-Arendt, K.J., 1993. Shoreline Changes along the North Yucatan Coast. In Coastlines of the Gulf of Mexico (S. Laska\& A. Puffer, eds.), a volume of the Coastlines of the Worldseries (O. Magoon. Ed.), American Society of Civil Engineers, New York. Proceedings of $8^{\text {th }}$ Symposium on Coastal and Ocean Management (Coastal Zone '93). July 19-23. New Orleans, pp. 103-117. 
Moreno, Eric I., Torres Acosta, Andrés A., Castro Borges, Pedro, 2004. Construcción del muelle de Progreso, Engineering Academy Magazine, Jan-April, year/vol. 8.No. 001. Universidad Autónoma de Yucatán, pp. 61-66

DHI, (2011). LITDRIFT, Longshore Current and Littoral Drift, User Guide. Horsholm Denmark, 106 pp.

DHI, (2011). LITPACK, An Integrated Modelling System for Littoral Processes And Coastline Kinetics, Short Introduction and Tutorial. Horsholm Denmark, 64 pp.

DHI, (2011). Spectral Waves FM Module (MIKE 21 SW), User Guide. Horsholm Denmark, 118 pp. 